\title{
Pandemics and the role of governments
}

\author{
VITO TANZI*
}

Former director, Fiscal Affairs Department, International Monetary Fund (IMF) and Honorary

President, International Institute of Public Finance

Received: June 17, 2021 • Revised manuscript received: July 18, 2021 • Accepted: August 15, 2021

(c) 2021 Akadémiai Kiadó, Budapest

\begin{abstract}
The recent pandemic has raised fundamental questions about the traditional role of government. That role has stressed the pursuit of national interests and identified the tools that governments should use in the pursuit of those interests. While over the past century the desirable role of the state was amended to include new objectives (such as equity and stabilization) the focus had remained national interests. This paper argues that this national focus has become increasingly anachronistic and damaging.
\end{abstract}

\section{KEYWORDS}

public goods and public bads, national and global interests, global institutional architecture, pandemics, climate change, and other major disasters, risks, uncertainties

\section{JEL CLASSIFICATION INDICES}

B4, D21, D4, D7, E6, F5, F6, H1, H4, P1, Q5

\section{INTRODUCTION}

Major crises, such as pandemics, may require changes in the routine, normal behaviour of governments. Taxation and public spending have traditionally been the major instruments available to countries' governments to promote the collective, or the national goals of their citizens. And national governments have been the main institutions through which countries' citizens pursue, or hope to pursue, their collective, national goals.

\footnotetext{
*Corresponding author. E-mail: vitotanzi@msn.com
} 
It is, of course, not easy to determine precisely what the collective needs/interests of a country's citizens are, at a given time, and how much public spending is necessary to promote and provide them. However, for the democratic countries which operate with market economies, the usual assumption has been that the collective needs can be determined democratically, through the electoral process; and that their determination suggests a given tax and public spending level. The democratic process also determines how the tax burden should be allocated among the country's citizens. This, at least, is the theory.

Naturally, there will always be some individuals, or some groups, who will think that the tax level, whatever it is, is too high; and others who will think that it is too low, and not sufficient to pay for the collective needs. Still others are likely to think that the tax burden is not allocated fairly among the citizens. The tax level and the tax structure are, of course, expected to pay attention to their economic efficiency and their equity aspects. In the time of crises, equity should become more important, if the economic system is to be considered fair, and if it wants to continue to be supported politically, and not encourage populism.

Over the last century, the views about the role of taxation changed significantly, as did the views about what the desirable government role should be (Musgrave 1959). Recognizing the strong opposition that continued to come from libertarian, or conservative, groups, the desirable government role was extended. It came to include, especially (a) the need to redistribute some income and wealth, from richer to poorer citizens, when the income distribution was not considered fair, and (b) attempts by governments to promote, with their policies, full, or fuller, employment of labour and capital, especially during the economic downturns.

The desirable tax level and the use of tax revenue has been normally assumed to be related to the assumed public needs during normal times and not during crises. Wars, at times, created exceptional situations needing more tax revenue. During wars the tax levels were often pushed up, to finance the military effort. In peaceful times the tax level and the tax structure were expected to return to the normal requirements of a market economy in normal times, one that was expected to operate efficiently, within a politically, democratic system and one that focused the government policies toward staying in power and winning the next elections. The taxes were expected to be efficient and sufficient to satisfy the routine and immediate needs of the citizens in a market economy. These have been, broadly, the main theoretical principles guiding the government role in market economies.

In normal situations, governments have been expected to keep the tax levels low and to focus the public spending toward satisfying the immediate, short run, needs of citizens and some easily quantifiable future needs, such as those related to health and pensions. Future but uncertain events and needs, have attracted much less if any attention. Governments that spent much money for the country to be better prepared to try to deal with such uncertain, future events would likely pay a political price in the elections.

Private enterprises that operate in competitive markets would also focus on minimizing current costs, in order to remain competitive. Neither governments nor enterprises would likely give many thoughts, or pay much attention, to potential, future and uncertain events, such as pandemics, major natural disasters, or say climate change, until these events actually materialized and made it impossible to ignore them. 


\section{PROBLEMS CREATED BY UNEXPECTED EVENTS}

Events and crises that may come in the future and that remain uncertain, such as those created by pandemics and by other major catastrophes, remain anomalies, or Acts of God. Little attention is paid to them. They do not and have not changed the economic behaviour of governments or enterprises, in the democratic countries with market economies, during the normal times. They have not entered in the routine policy decisions of governments, or in the planning of private enterprises. Future random events are impossible to predict statistically, and the same is the case with some risky events such as aging in the Frank Knight (1921) definition, in both their timing and their severity. Therefore, they do not force governments and private enterprises to make preparations, to better deal with them, when they finally come. The timing of pandemics cannot be predicted, and neither can their severity.

However, over many centuries, there have been major pandemics, such as the Black Plague of 1346-1352 in Europe that killed at least a third of the European population, and the Spanish Flu of 1918-1919, that killed more people than had the First World War. There have been also other major, natural disasters (major hurricanes, earthquakes, tsunamis, and others) that happened, some at a time when the role of governments and their capacity to act had been very limited.

When the disasters came, few citizens had expected the governments to be able to do much. These pandemics and the other catastrophes had been considered as the "Acts of God" over which there was little that could be done. Wars, however, had been in a different category, because they could not be considered as the Acts of God, and, to some extent, they could be anticipated.

In recent decades, business cycles, such as the Great Depression of the 1930s and the Great Recession of 2008-9, attracted the attention of economists and policy makers (Solimano 2020). This led to expectations that governments could and should adopt some policies to deal with them, when they came, and even to adopt some policies in anticipation of their coming. These economic cycles had some regularity to them. This led to the Keynesian Revolution, a "revolution" that called on governments to increase spending during recessions, and to finance the higher spending with fiscal deficits. The Keynesian Revolution also led to calls for some other policies, such as permanently higher public spending, and for the use of built-in stabilizers, that would help reduce, automatically, the severity of the recessions. This was probably the first call, by economists on governments, to deal, on a permanent or regular basis, with crises of an economic origin.

There were not similar calls to prepare for and to deal with the eventual coming of natural catastrophes. Their randomness in time and severity prevented this, or made it more difficult. The way economies and governments operate, in democratic, market economies, did not and does not encourage governments and private enterprises, in normal times, to adopt policies that would make it easier for countries to deal with the catastrophes, when they came. For example, this might require spending more money for hospital beds, for research about pathogens, for building more protections against floods, and for building stronger buildings against earthquakes.

For governments, there would not be any political advantages, and only political costs, in doing so, because the benefits would be seen later, and at times much later. On the other hand, the costs, in higher taxes or in more regulations, would be felt immediately. Many citizens would 
likely see those expenses as unnecessary. The frequency of political elections, (that make the relevant time horizon of democratic governments short), and political pressures to keep tax levels low and to use the resources to meet the immediate needs, would prevent democratic governments from allocating significant resources to provide better protection to citizens from future, uncertain events. A government that invested large resources in trying to protect citizens against such future uncertain events would likely be criticized, for wasting taxpayers' money. Uncertainty would play against potentially better future security.

To some extent governments have occasionally relied on regulations, rather than on spending, to promote better safety codes against some of such events. For example, in areas subject to earthquakes, such as California, Chile or Japan, they have strengthened the building codes. In areas subject to hurricanes, they have imposed some regulations to keep buildings at some distance from the coastline. By increasing the cost of housing, governments' regulations have at times been criticized, as they are in California.

On the side of the private sector, the forces of competitions also promote actions, or behaviour, that do not help the enterprises in dealing with eventual but uncertain catastrophic events, when they come, or even with recessions, that may affect them more directly. Private enterprises, operating in highly competitive markets, face strong incentives to keep their costs low (Tanzi 2021). They do so by squeezing real wages, minimizing their work forces, and keeping inventories down. The CEOs of corporations have an incentive to distribute the profits of the corporations to the shareholders, or to use them to buy shares of their own corporations. This helps to keep the shareholders happy, to justify the CEOs high compensation packages, and to reduce the taxes that the owners of the corporations pay on their earnings, because unrealized capital gains are not taxed.

Enterprises are also encouraged to make greater use of debt to finance their investments or, even, to buy their own shares. The deductibility of the interest paid on the debt in the calculation of the taxable profits makes this policy particularly attractive. When the cost of borrowing is kept low, by central banks' policies, as it has been kept in current years, these incentives are stimulated, leading to high shares of private debt and lower tax revenue.

These and other actions contribute to the conditions that make specific enterprises more vulnerable to crises, when the crises come. If the enterprises are "too big to fail", they can hope that the government will come to their rescue, in case of crisis, as happened to some during the Great Recession of 2009-2010. Often the workers are the ones that bear the major costs, because they lose their jobs, their incomes and, in some countries, such as the USA, even their health insurances.

The above moves the focus, from what governments and enterprises should have done, but did not do, in anticipation of random or uncertain crises and disasters, including pandemics, to what they should do, when the disasters become a reality, as did Covid 19 in 2020. This question is addressed in the next section, with special reference to the current pandemic, and with reference especially to the US situation. We shall focus on shortcomings in the traditional role of the government.

\section{POLICIES DURING PANDEMICS}

The first obvious observation concerning governments is that when major disasters, such as pandemics, are realistic future events, even though their statistical possibilities cannot be 
estimated, as it can for insurable risks, it would always be wise for governments to keep some space in their fiscal accounts, so that it would be easier for them to step in with additional spending, when the time to do so has come. This implies that a government that is already burdened by high debt, and is relying on high and bad taxes, will have less degrees of freedom to act, than one that has a low debt and more fiscal space. Initial fiscal conditions are always important.

This, of course, is an argument against those economists who, in recent years, have complained about what they have called "austerity" policies by governments, in times which were largely normal. These economists have complained even when public spending, public debts, and fiscal deficits were already high. It is also an argument against the economists who argue that there is almost no limit to government debt, and that government that borrows in their own currency can never run into difficulties. Proponents of this so called New Monetary Theory have been arguing along these lines.

Similar observations can be made concerning the behaviour of private enterprises. In this context the comparison between the behaviour of American and Japanese enterprises may be of some interest. In good times, the Japanese enterprises tend to hold larger shares of their profits. They use them to retain their work force during bad times. American companies do not. In bad times they simply lay off their workers. As a consequence, the unemployment rate fluctuates less in Japan than in the USA.

In this context it should be pointed out that workers normally depend on their wages for their purchasing power. When they lose their jobs, they lose most of their incomes. On the other hand, wealthy individuals normally have accumulated wealth to fall on. Many allocate their total wealth on shares in many different corporations or on different assets. They thus "spread their eggs in many baskets". Therefore, the poor performance of single enterprises or asset affects their total purchasing power much less. Furthermore, the tax treatment of capital income is generally much lighter than that of wages.

Let us now come more directly to the role of taxation in the times of crisis, starting with some observations largely based on the US experience. During the on-going pandemics, employment collapsed, and millions of workers lost their jobs. Many of them did not have assets to fall on. Unemployment claims were high, and they were expected to remain high for some time. At the time of writing this paper (June 2021), the future impact of the pandemics on the economy remained highly uncertain, and thus, worrisome. Consumer confidence continues to be low. Supply chains have been disrupted and global trade has been negatively affected. Public debt is very high and continue to grow. Elsewhere many governments have found it impossible to meet their existing budget rules, where these rules exist as in the European Union. They have been relying excessively on public borrowing, mostly directly from central banks, in what used to be called "inflationary finance". In the past that normally led to high inflation and to other problems (Tanzi 1978). Will this time be different?

A remarkable thing about this gloomy economic situation is that the stock markets are doing very well. In the USA its current level is at a historical high. This disconnect between what has been happening in the real economy, and especially to workers in so called "essential occupations", and what had been happening to wealthy citizens, to many of those in presumably "nonessential" occupation, is nothing short of extraordinary. It is almost obscene, and not a good selling card for the market economy. 
The reasons for this disconnect are largely two: tax policy in recent decades and recent monetary policy. It would be impossible to discuss those policies in detail here. Therefore, we shall limit ourselves to some rather general observations, starting with the one that, over recent decades, the share of total income and wealth received by a small minority (the one percent?) has increased remarkably. These are the individuals benefiting from the current behaviour of the stock market and asset prices.

In spite of some common beliefs about crises as times for opportunities, major crises are generally not the best times to make major and permanent tax or policy reforms. During crises it should be better to focus on the immediate needs of citizens and leave the fundamental changes to normal, later times. The immediate needs are those of individuals who have lost their jobs and who do not have other incomes to sustain them. Poverty rates have gone up. These poor people are the individuals who should be helped by governments' assistance during the pandemic. That assistance could be financed in part by public debt and in part by increasing taxes on those with the highest incomes and wealth. Taxes should definitely play a role. Given the behaviour of the stock market, Tobin taxes on shares transaction could be used.

These taxes could be temporary, lasting for the period of the pandemic and replaced when the economic situation goes back to normal. They would make the high income and high wealth individuals share in the costs of the pandemics and make the prevailing economic system more equitable.

On their part, central banks should pay some or more attention to the distributional or equity aspects of their monetary policies, because their policies have become progressively indistinguishable in their macro aspects from fiscal policies. Because of this, central bankers cannot any longer assume that equity is not an objective that they can ignore. Their recent policies have made easier for governments to finance their spending with debts rather than taxes, and have made wealthier people access cheap credit that they could invest in the booming stock exchanges. From an equity point of view this leaves much to be desired, and equity should remain an important characteristic of the economic systems.

\section{NATIONAL FOCUS AND GLOBAL PUBLIC GOODS}

Another aspect of the traditional role of government that becomes questionable during major crises, and especially during pandemics, is the continuing focus of that role on national goals, as if the rest of the world did not exist, or did not count. The Covid pandemic has made it clear that countries' economies and developments are now greatly interconnected. Dealing with a pandemic can no longer be a country-by-country, or a national, effort. It must be a world effort in which richer countries, which are more able to carry the weight, must assist the poorer countries. This has become clearly evident in the need to share vaccines.

The pandemic is a classic "public good", or better a "public bad", on a global scale. And there are many such goods and bads. The growing importance of these global "public goods" has exposed the limitation of a government role that has continued to stress national goals. It is the time to wake up to the fact that the world needs a different institutional architecture and that we focus on creating a better one than the one that now exists (Tanzi, forthcoming). 


\section{REFERENCES}

Knight, F. H. (1921), (1964): Risk, Uncertainty and Profit. New York: Century Press.

Musgrave, R. A. (1959): The Theory of Public Finance. New York and London: McGraw-Hill.

Solimano, A. (2020): A History of Big Recession in the Long Twentieth Century. Cambridge University Press.

Tanzi, V. (1978): Inflation, Real Tax Revenue, and the Case for Inflationary Finance: Theory with an Application to Argentina. IMF Staff Papers, 25(4).

Tanzi, V. (2021): Perfect Markets, Perfect Democracy and Pandemics. TIGER Working Paper Series, No. 142.

Tanzi, V. (forthcoming): Fragile Futures: The Uncertain Economics of Disasters, Pandemics and Climate Change. Cambridge University Press. 